\title{
Uranium Neutron Coincidence Collar Model Utilizing ${ }^{3} \mathrm{He}$
}

Edward R. Siciliano Jeremy L. Rogers John E. Schweppe Azaree T. Lintereur Richard T. Kouzes

July 2012

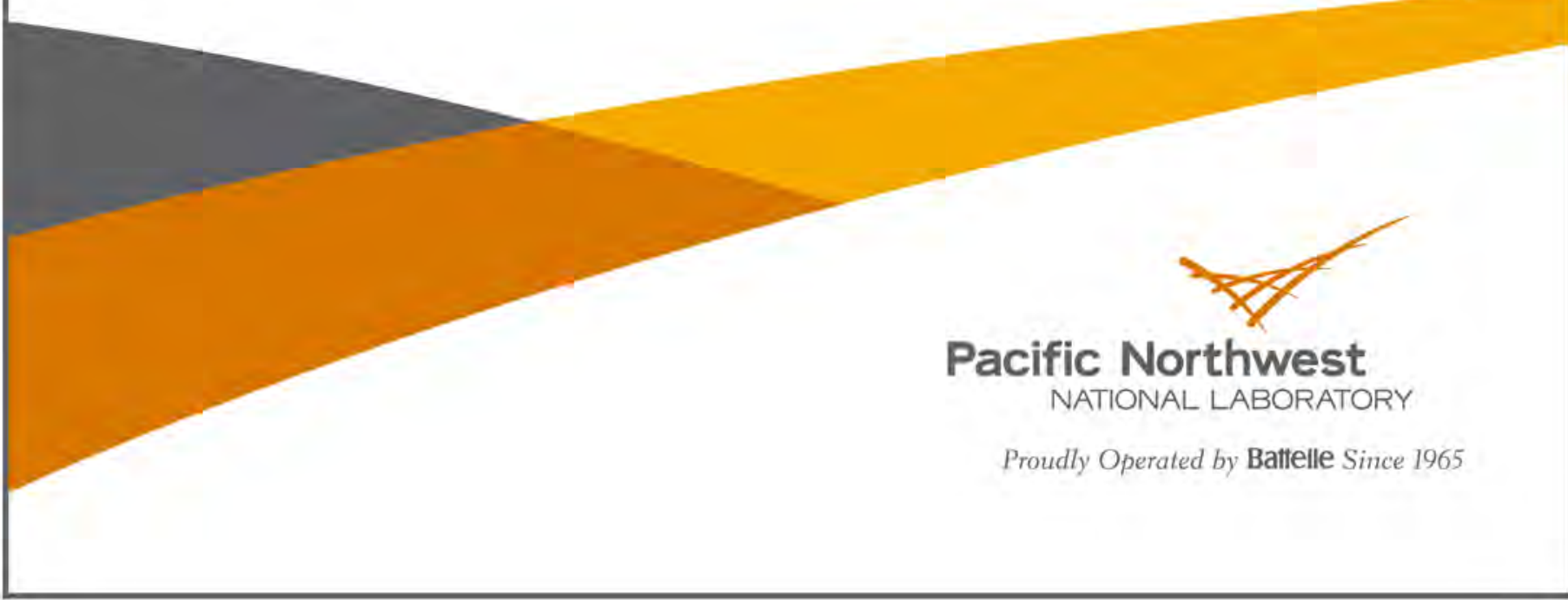




\title{
DISCLAIMER
}

This report was prepared as an account of work sponsored by an agency of the United States Government. Neither the United States Government nor any agency thereof, nor Battelle Memorial Institute, nor any of their employees, makes any warranty, express or implied, or assumes any legal liability or responsibility for the accuracy, completeness, or usefulness of any information, apparatus, product, or process disclosed, or represents that its use would not infringe privately owned rights. Reference herein to any specific commercial product, process, or service by trade name, trademark, manufacturer, or otherwise does not necessarily constitute or imply its endorsement, recommendation, or favoring by the United States Government or any agency thereof, or Battelle Memorial Institute. The views and opinions of authors expressed herein do not necessarily state or reflect those of the United States Government or any agency thereof.

\author{
PACIFIC NORTHWEST NATIONAL LABORATORY \\ operated by \\ BATTELLE \\ for the \\ UNITED STATES DEPARTMENT OF ENERGY \\ under Contract DE-AC05-76RL01830
}

Printed in the United States of America
Available to DOE and DOE contractors from the
Office of Scientific and Technical Information,
P.O. Box 62, Oak Ridge, TN 37831-0062;
ph: (865) 576-8401
fax: (865) 576-5728
email: reports@adonis.osti.gov

Available to the public from the National Technical Information Service, U.S. Department of Commerce, 5285 Port Royal Rd., Springfield, VA 22161

ph: (800) 553-6847

fax: (703) 605-6900

email: orders@ntis.fedworld.gov

online ordering: http://www.ntis.gov/ordering.htm 
PNNL-21581

\section{Uranium Neutron Coincidence Collar Model Utilizing ${ }^{3} \mathrm{He}$}

Edward R. Siciliano

Jeremy L. Rogers

John E. Schweppe

Azaree T. Lintereur

Richard T. Kouzes

July 2012

Pacific Northwest National Laboratory

Richland, Washington 99352 


\section{Executive Summary}

The Department of Energy Office of Nuclear Safeguards (NA-241) is supporting the project "Coincidence Counting With Boron-Based Alternative Neutron Detection Technology" at Pacific Northwest National Laboratory (PNNL) for development of an alternative neutron coincidence counter. The goal of this project is to design, build and demonstrate an alternative system based upon boron-lined proportional tubes in a configuration typical for ${ }^{3} \mathrm{He}$-based coincidence counter applications.

The specific application selected for boron-lined tube replacement in this project was one of the Uranium Neutron Coincidence Collar (UNCL) designs. This report, providing results for model development of a UNCL, is a deliverable under Task 2 of the project.

The current UNCL instruments utilize ${ }^{3} \mathrm{He}$ tubes. As the first step in developing and optimizing a boron-lined proportional counter based version of the UNCL, models of eight different ${ }^{3} \mathrm{He}-$ based UNCL detectors currently in use were developed and evaluated. Neutron-count efficiencies and corresponding die-away times from those eight modeled systems are reported, and compared to measurements for those systems with values reported in the literature. The reported experimental measurements for efficiencies and die-away times agree to within $10 \%$. 


\section{Acronyms and Abbreviations}

BWR

DOE

$\varepsilon$

FOM

HEU

IAEA

LANL

MOX

PANDA

PNNL

$\mathrm{Pu}$

PWR

$\tau$

UNCL boiling-water reactor

U.S. Department of Energy

detection efficiency

figure-of-merit

highly enriched uranium

International Atomic Energy Agency

Los Alamos National Laboratory

mixed oxide (reactor fuel)

Passive Nondestructive Assay of Nuclear Materials

Pacific Northwest National Laboratory

plutonium

pressurized-water reactor

die-away time

Uranium Neutron Coincidence Collar 


\section{Contents}

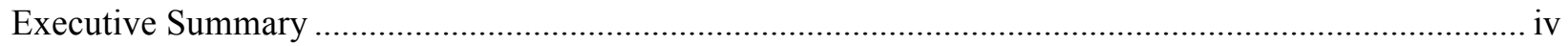

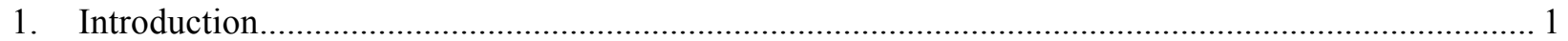

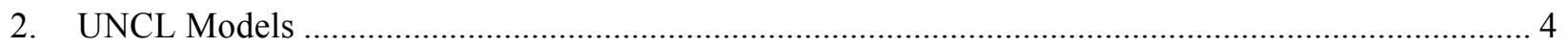

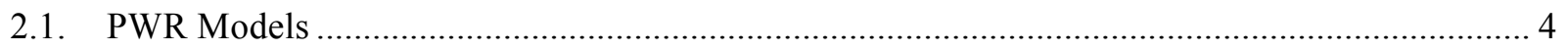

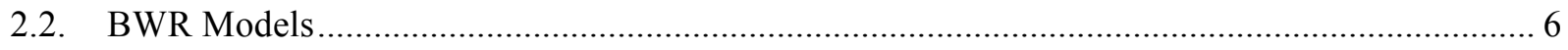

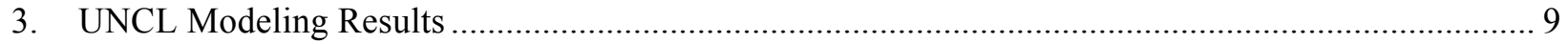

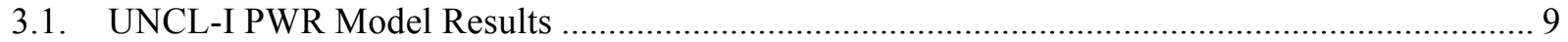

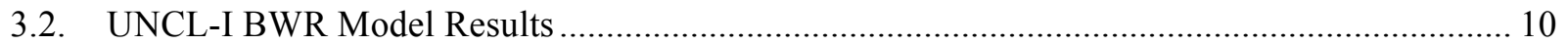

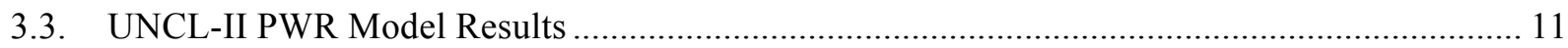

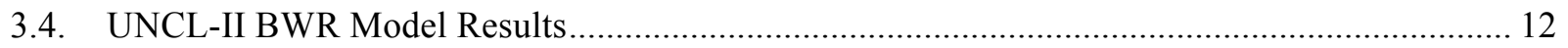

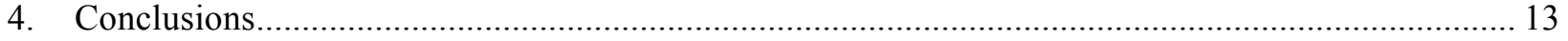

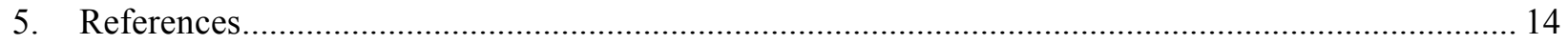

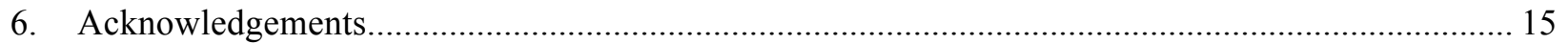

7. Appendix A: Uranium Neutron Coincidence Collar ....................................................................... 16

7.1. Canberra Uranium Neutron Coincidence Collar........................................................................ 17

7.2. LANL Uranium Neutron Coincidence Collar .......................................................................... 22 


\section{Figures and Tables}

\section{Figures}

Figure 2.1. Layout of UNCL-II (left) and UNCL-I (right) active PWR models as seen from above.......... 4

Figure 2.2. Layout of the UNCL-I PWR model for active (left) and passive (right) measurements........... 5

Figure 2.3. Side views of the UNCL-II PWR model. ............................................................................... 5

Figure 2.4. Views of the UNCL-II PWR model for the active source holder. ........................................ 6

Figure 2.5. Views of the UNCL-II PWR model for active (left) and passive (right) configurations. .......... 6

Figure 2.6. Comparison of the active UNCL-II BWR model (left) and the UNCL-I BWR model (right). . 7

Figure 2.7. Comparison of the passive UNCL-II BWR model (left) and the UNCL-I BWR model (right). 7

Figure 2.8. Comparison of the active UNCL-II PWR model (left) and the BWR model (right). ............... 8

Figure 2.9. Comparison of the passive UNCL-II PWR model (left) and the BWR model (right)............. 8

Figure 3.1. Results for active UNCL-I PWR die away time computed with the model........................... 9

Figure 3.2. Results for passive UNCL-I PWR die away time computed with the model........................ 10

Figure 4.1. Results for active UNCL-II PWR die away time computed with the model. ........................ 11

Figure 7.1. Uranium Neutron Coincidence Collar (UNCL) [ESARDA 2005] ........................................ 17

Figure 7.2. Canberra JCC-71 UNCL in Passive Configuration [Canberra 2011]..................................... 18

Figure 7.3. Canberra JCC-73 UNCL in Active Configuration for PWR fuel [Canberra 2011]. ............... 19

Figure 7.4. Canberra JCC-72 UNCL Active Configuration for BWR or CANDU fuel [Canberra 2011]. 19

Figure 7.5. Canberra JCC-71 UNCL Schematic Active Configuration for PWR fuel [Canberra 2011].... 20

Figure 7.6. Canberra JCC-71 UNCL Schematic Passive Configuration for PWR fuel [Canberra 2011]. . 21

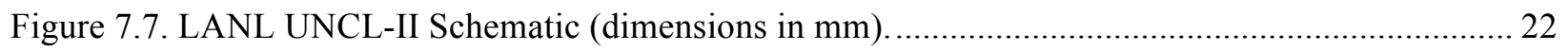

\section{Tables}

Table 1.1. Characteristics of the eight UNCL configurations............................................................. 2 


\section{Introduction}

The Department of Energy Office of Nuclear Safeguards (NA-241) is supporting the project Coincidence Counting With Boron-Based Alternative Neutron Detection Technology at Pacific Northwest National Laboratory (PNNL) for development of a neutron coincidence counter without ${ }^{3} \mathrm{He}$. This report, providing results for model development of a Uranium Neutron Coincidence Collar (UNCL), is a deliverable under Task 2 of the project.

Coincidence counting is used in applications where the mass of plutonium (Pu) or uranium (U) isotopes needs to be determined for safeguards applications. Such counters use banks of multiple neutron detector tubes surrounding a sample to provide high efficiency detection of neutrons emitted from the sample. A previous report provided an overview of the different coincidence counter configurations in use [Kouzes et al. 2012]. The configuration discussed in this paper, the UNCL, is intended for use with fresh low-enrichment uranium or mixed oxide (MOX) fuels, and may either be operated in active mode for the former, or passive mode for the latter.

There have been two generations of UNCL assemblies, the original UNCL (referred to in this report as the "UNCL-I") was designed before 1981 [Menlove 1981], and the UNCL-II was introduced in 1989 [Menlove et al. 1990]. The difference between the two versions is in the number of tubes, adjustability of the "collar," and some other design details.

Each UNCL assembly can, in principle, be used as an active or passive detector. The active detector is used when measuring low-enrichment uranium fuel and includes an AmLi neutron source to induce fission in the sample being measured. The passive detector is used when assaying fuel that contains $\mathrm{Pu}(\mathrm{MOX})$, which does not require an external neutron source. The active UNCL configuration includes three banks of ${ }^{3} \mathrm{He}$ detectors and an AmLi source holder on the fourth side. The passive UNCL configuration includes four slabs of ${ }^{3} \mathrm{He}$ detectors. The Appendix shows schematics for these configurations as produced by Canberra Industries.

In addition, UNCL assemblies can be used for measurements of either boiling water reactor (BWR) or pressurized water reactor (PWR) fuel. The BWR assembly is smaller, and the UNCL configurations for that application have smaller sample cavities. Because the banks forming the "collar" in the UNCL-I design are three separate pieces, the same UNCL-I detector used for PWR applications can be adjusted for BWR applications by moving the two side slabs closer. Because the UNCL-II "collar" is one piece, a distinct, smaller detector assembly is built for BWR fuel. The BWR assembly is also used for measurements of CANDU fuel [Canberra 2011].

There are thus eight potential types of UNCL assemblies (UNCL-I or UNCL-II, active or passive, PWR or BWR). Table 1.1 shows characteristics of these eight UNCL configurations that utilize ${ }^{3} \mathrm{He}$ proportional tubes. The number of ${ }^{3} \mathrm{He}$ tubes used in each assembly is shown, along with the moles of gas. The dimensions shown are the height $(\mathrm{H})$, length $(\mathrm{L})$ and width $(\mathrm{W})$ of the fuel cavity. The total count efficiency $(\varepsilon)$, die away time $(\tau)$ and Figure of Merit (FOM), computed as $\varepsilon^{2} / \tau$ [Henzlova et al. 2010; Henzlova et al. 2012], are shown, where reported. The efficiency shown is measured with a ${ }^{252} \mathrm{Cf}$ source in the center of the fuel cavity. The model results shown will be discussed in a later section of this report.

All ${ }^{3} \mathrm{He}$ tubes used in these assemblies have $2.54 \mathrm{~cm}$ (1") outer diameter, a $33 \mathrm{~cm}$ (13") active length, and are filled with four atmospheres of ${ }^{3} \mathrm{He}$ (assumed $22.5^{\circ} \mathrm{C} / 68^{\circ} \mathrm{F}$ ). The aluminum clad tubes are GE Reuter Stokes model \# RS-P4-2813-107. 
A number of these UNCL configurations are sold by Canberra Industries, Inc. (Meriden, CN) as the JCC-1 (UNCL-I passive PWR), JCC-2 (UNCL-II active BWR) and JCC-3 (UNCL-I active PWR).

Table 1.1. Characteristics of the eight UNCL configurations.

\begin{tabular}{|c|c|c|c|c|c|c|c|c|}
\hline \multirow{3}{*}{ Detector } & \multirow{3}{*}{$\begin{array}{c}\text { Total \# Tubes, } \\
\text { Configuration, \& } \\
\text { Fuel Cavity } \\
\text { H x L x W (cm) }\end{array}$} & \multirow{3}{*}{$\begin{array}{l}\text { Total } \\
\text { No. } \\
\text { Moles }\end{array}$} & \multicolumn{6}{|c|}{ Efficiency $(\varepsilon)$, Die-Away Time $(\tau) \&$ FOM $=\varepsilon^{2} / \tau$} \\
\hline & & & \multicolumn{3}{|c|}{ Measured } & \multicolumn{3}{|c|}{ Models } \\
\hline & & & $\varepsilon$ & $\tau(\mu s)$ & $\begin{array}{c}\text { FOM } \\
(\%)^{2} / \mu \mathrm{s}\end{array}$ & $\varepsilon$ & $\tau(\mu \mathbf{s})$ & $\begin{array}{c}\text { FOM } \\
(\%)^{2} / \mu \mathrm{s}\end{array}$ \\
\hline $\begin{array}{l}\text { UNCL-I } \\
\text { Active } \\
\text { BWR }\end{array}$ & $\begin{array}{l}18 \text { tubes } \\
3 \text { Rectangular banks, } \\
41.4 \times 16.5 \times 23.4\end{array}$ & 0.44 & $13.5 \% * * *$ & & & $12.5 \%$ & 50 & 3.1 \\
\hline $\begin{array}{l}\text { UNCL-I } \\
\text { Active } \\
\text { PWR } \\
\end{array}$ & $\begin{array}{l}18 \text { tubes } \\
3 \text { Rectangular banks } \\
41.4 \times 23.4 \times 23.4\end{array}$ & 0.44 & $10.3 \% * * *$ & & & $9 \%$ & 49 & 1.7 \\
\hline $\begin{array}{l}\text { UNCL-I } \\
\text { Passive } \\
\text { BWR }\end{array}$ & $\begin{array}{l}24 \text { tubes } \\
4 \text { Rectangular banks } \\
41.4 \times 16.5 \times 23.4\end{array}$ & 0.59 & & & & $16.3 \%$ & 51 & 5.2 \\
\hline $\begin{array}{l}\text { UNCL-I } \\
\text { Passive } \\
\text { PWR }\end{array}$ & $\begin{array}{l}24 \text { tubes } \\
4 \text { Rectangular banks } \\
41.4 \times 23.4 \text { x } 23.4\end{array}$ & 0.59 & $\begin{array}{c}11.5 \% \\
( \pm 10 \%)^{\#}\end{array}$ & $\sim 51 *$ & 2.6 & $12.2 \%$ & 50 & 3.0 \\
\hline $\begin{array}{l}\text { UNCL-II } \\
\text { Active } \\
\text { BWR }\end{array}$ & $\begin{array}{l}16 \text { tubes } \\
3 \text { Rectangular banks } \\
41.3 \times 16.5 \times 16.5\end{array}$ & 0.39 & $\begin{array}{c}15.3 \% * * \\
15.4 \% * * * \\
13.5 \% \\
( \pm 10 \%)^{\# \#}\end{array}$ & $58 * *$ & 4.0 & $14.9 \%$ & 53 & 4.2 \\
\hline $\begin{array}{l}\text { UNCL-II } \\
\text { Active } \\
\text { PWR }\end{array}$ & $\begin{array}{l}20 \text { tubes } \\
3 \text { Rectangular banks } \\
41.3 \times 23.5 \times 23.5\end{array}$ & 0.49 & $\begin{array}{c}12.6 \% * * * \\
12.5 \% \\
( \pm 10 \%)^{\# \#}\end{array}$ & & & $12.3 \%$ & 53 & 2.9 \\
\hline $\begin{array}{l}\text { UNCL-II } \\
\text { Passive } \\
\text { BWR }\end{array}$ & $\begin{array}{l}20 \text { tubes } \\
4 \text { Rectangular banks } \\
41.3 \times 16.5 \times 16.5\end{array}$ & 0.49 & $\mathrm{NA} * * * *$ & & & $19.1 \%$ & 54 & 6.8 \\
\hline $\begin{array}{l}\text { UNCL-II } \\
\text { Passive } \\
\text { PWR }\end{array}$ & $\begin{array}{l}26 \text { tubes } \\
4 \text { Rectangular banks } \\
41.3 \times 23.5 \times 23.5\end{array}$ & 0.64 & NA**** & & & $16.3 \%$ & 53.1 & 5.0 \\
\hline
\end{tabular}

* $\quad$ Evaluated from reported $64 \mu$ s optimal gate width of 1.257 times tau

** From [Croft et al. 2011] using ${ }^{252} \mathrm{Cf}$ centered in sample chamber

*** From [Menlove et al. 1990] using ${ }^{252} \mathrm{Cf}$ centered in sample chamber

**** Not measured at LANL, Howard Menlove, private communication, July 2012

\# $\quad$ From [Canberra 2011] for JCC-71 using active measurement

\#\#\# From [Canberra 2011] for JCC-72 using active measurement

\#\#\# From [Canberra 2011] for JCC-73 using active measurement 
The die-away time $(\tau)$ of a counter is the average lifetime of a fission neutron in the counter. In principle, it includes termination by being counted, stopped but not counted, or escaping. The values listed as "measured" in Table 1.1 were obtained by using the relationship:

$$
\frac{R_{1}}{R_{2}}=\frac{1-e^{-\frac{G_{1}}{\tau}}}{1-e^{-\frac{G_{2}}{\tau}}}
$$

where $R_{1}$ is the coincident rate with a gate width of $G_{1}$, and $R_{2}$ is the coincident rate with a gate width of $\mathrm{G}_{2}$ [PANDA 1991; Chapter 16]. If $\mathrm{G}_{2}$ is set equal to $2 \mathrm{G}_{1}$ then:

$$
\tau=\frac{-G_{1}}{\ln \left(\frac{R_{2}}{R_{1}}-1\right)}
$$

For the model results listed in Table 1.1, the effective die-away times were obtained with a chisquared fit of a single exponential to the capture tallies as a function of time. Although this is a useful method for relative comparison of model configurations, a more precise comparison to measurements may be obtained by calculating gate width and coincidence rate values for use in Eq. 1.2. For the objectives of this work, however, the difference between the two methods is not considered significant.

The efficiency of the various UNCL configurations is seen in the table to vary from about $10 \%$ $15 \%$, and the die away time is approximately $50 \mu \mathrm{s}$. The figure of merit is measured to be 4.0 for the active BWR UNCL-II. In developing a boron-lined version of the UNCL, this active BWR UNCL-II is the benchmark system that will be used since it is well characterized [Croft et al. 2011].

In Table 1.1, the three Canberra UNCL configurations have been attributed to their approximate model equivalent based on the number of ${ }^{3} \mathrm{He}$ tubes used. This equivalence is approximate since details between the LANL designs and the Canberra designs probably differ. In developing some of the models, estimates were made of some of the geometries based on pictures of the equipment or on likely sizes. Thus, the model results obtained may vary somewhat from actual physical systems with regard to performance. 


\section{UNCL Models}

This paper focuses on the creation of Monte Carlo N-Particle (MCNPX) [Pelowitz 2011] models of UNCL counters that utilize ${ }^{3} \mathrm{He}$ tubes for the neutron detectors. Detail on the UNCL counters is provided in the Appendix of this report (extracted from a previous report [Kouzes et al. 2012]). Both the UNCL-I and the UNCL-II were developed at Los Alamos National Laboratory (LANL), and they differ mostly in the number of ${ }^{3} \mathrm{He}$ tubes used. The models were created using the dimensional information provided by LANL [Menlove 1981; Menlove et al. 1990] for the UNCL-II and from Canberra Industries literature [Canberra 2011] for the UNCL-I.

\section{1. $\quad$ PWR Models}

Figure 2.1 shows a view from above of the active UNCL-I and UNCL-II PWR models that were created. The detectors differ in the number of tubes and the amount of moderator material. Some simplifications of the UNCL-I model were made, as can be seen by comparing this figure to those in the Appendix.

Figure 2.2 shows a comparison of the models of the UNCL-I PWR in active and passive configurations. For all models of the passive mode, the source holders were replaced with a fourth bank of detectors. This bank was assumed to be identical to the bank on the opposite side of the cavity.
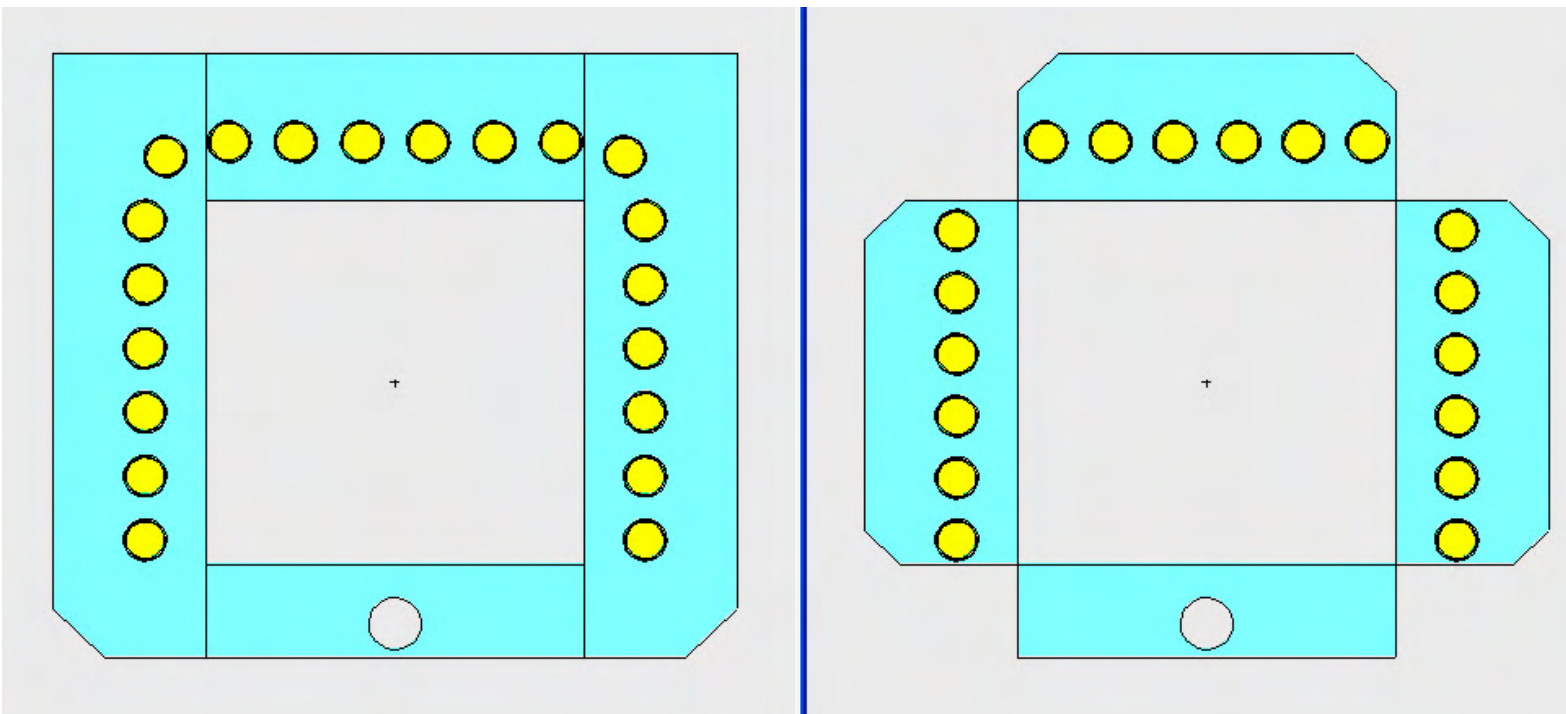

Figure 2.1. Layout of UNCL-II (left) and UNCL-I (right) active PWR models as seen from above. 


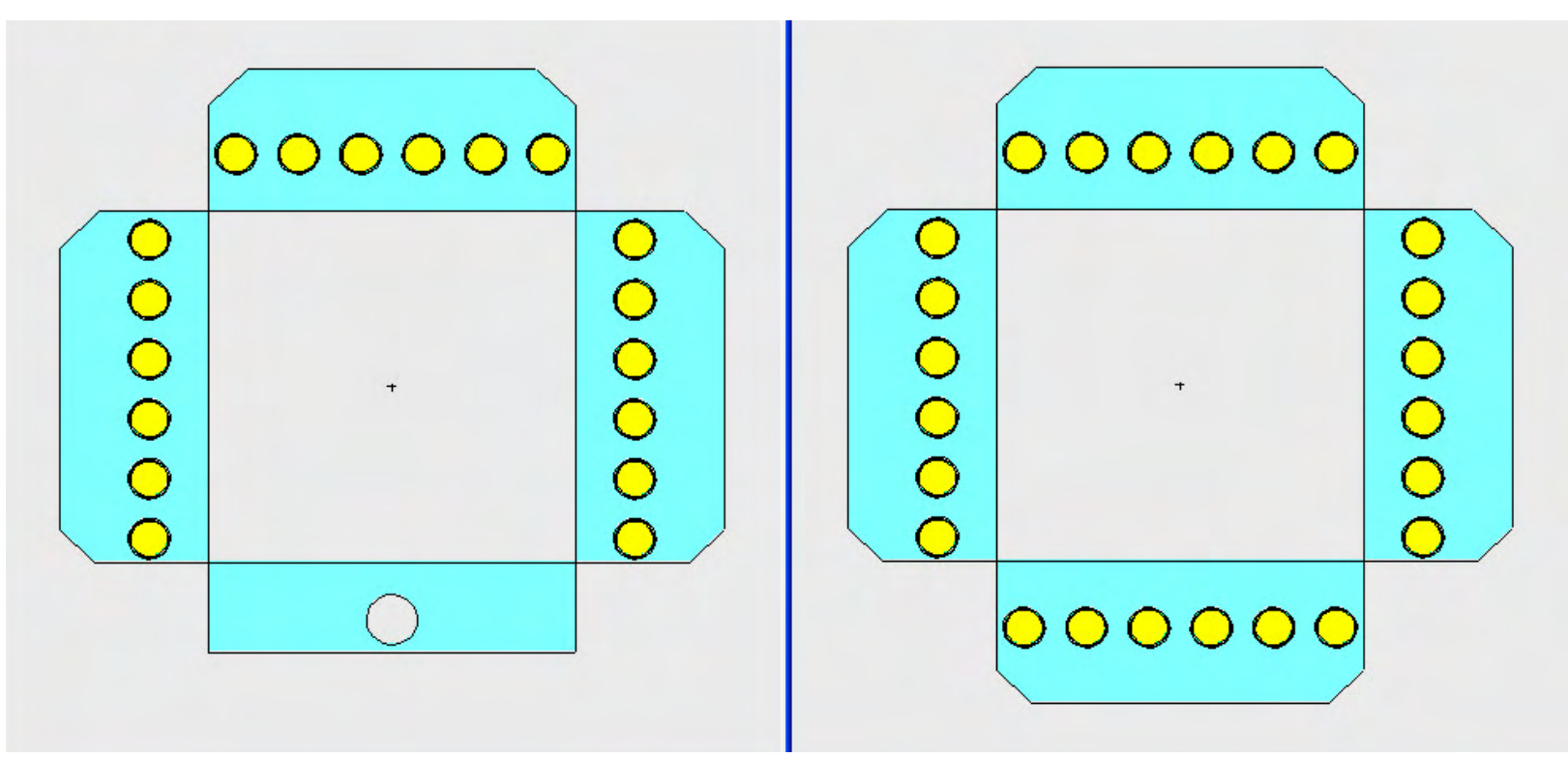

Figure 2.2. Layout of the UNCL-I PWR model for active (left) and passive (right) measurements.

Figure 2.3 shows a side view of the UNCL-II PWR model, where the detector is sitting on a table.

Figure 2.4 shows the model of the source holder for the active UNCL-II PWR model.

Figure 2.5 shows a comparison of the active and passive UNCL-II PWR models as seen from above, with the source holder replaced with a bank of detectors in the passive version.

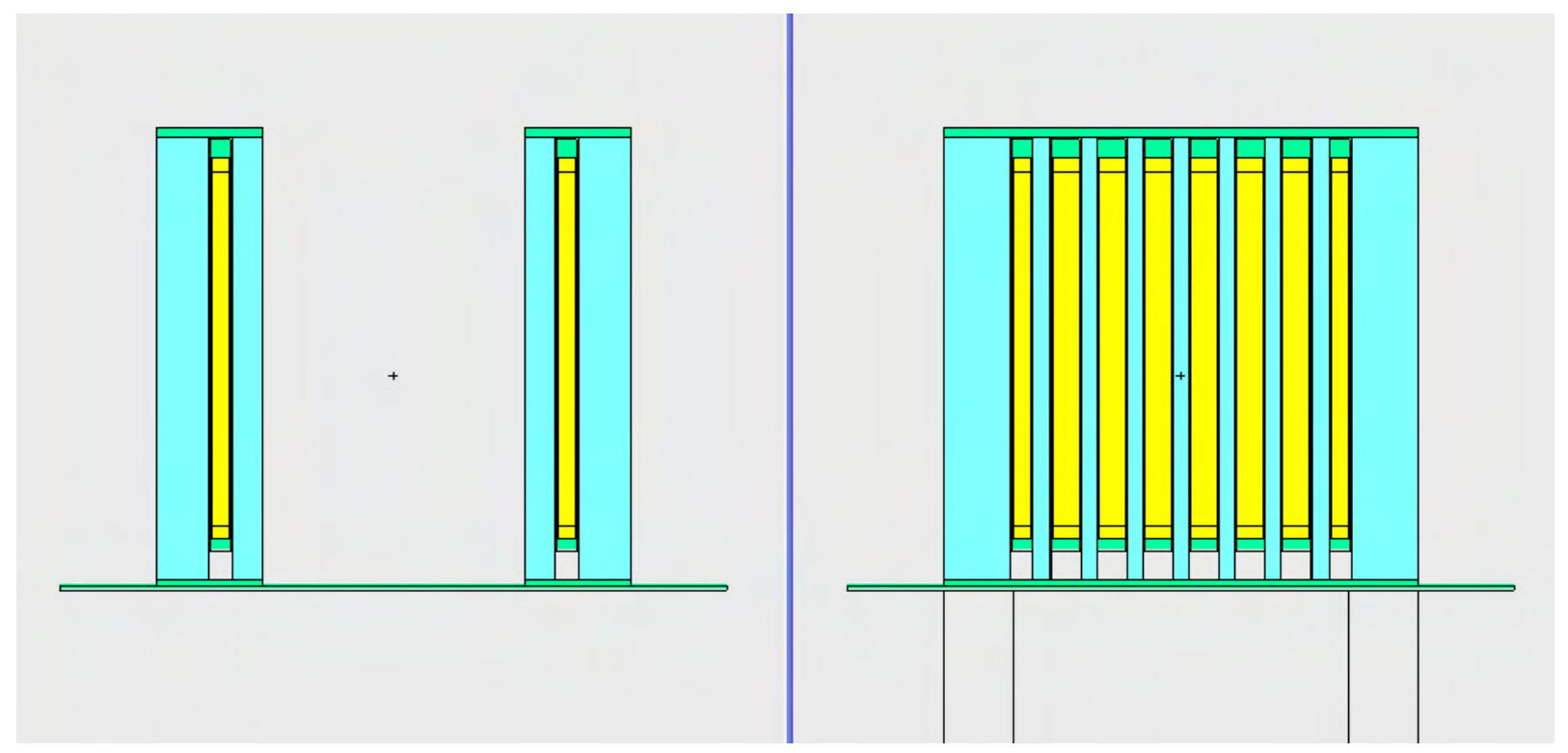

Figure 2.3. Side views of the UNCL-II PWR model. 


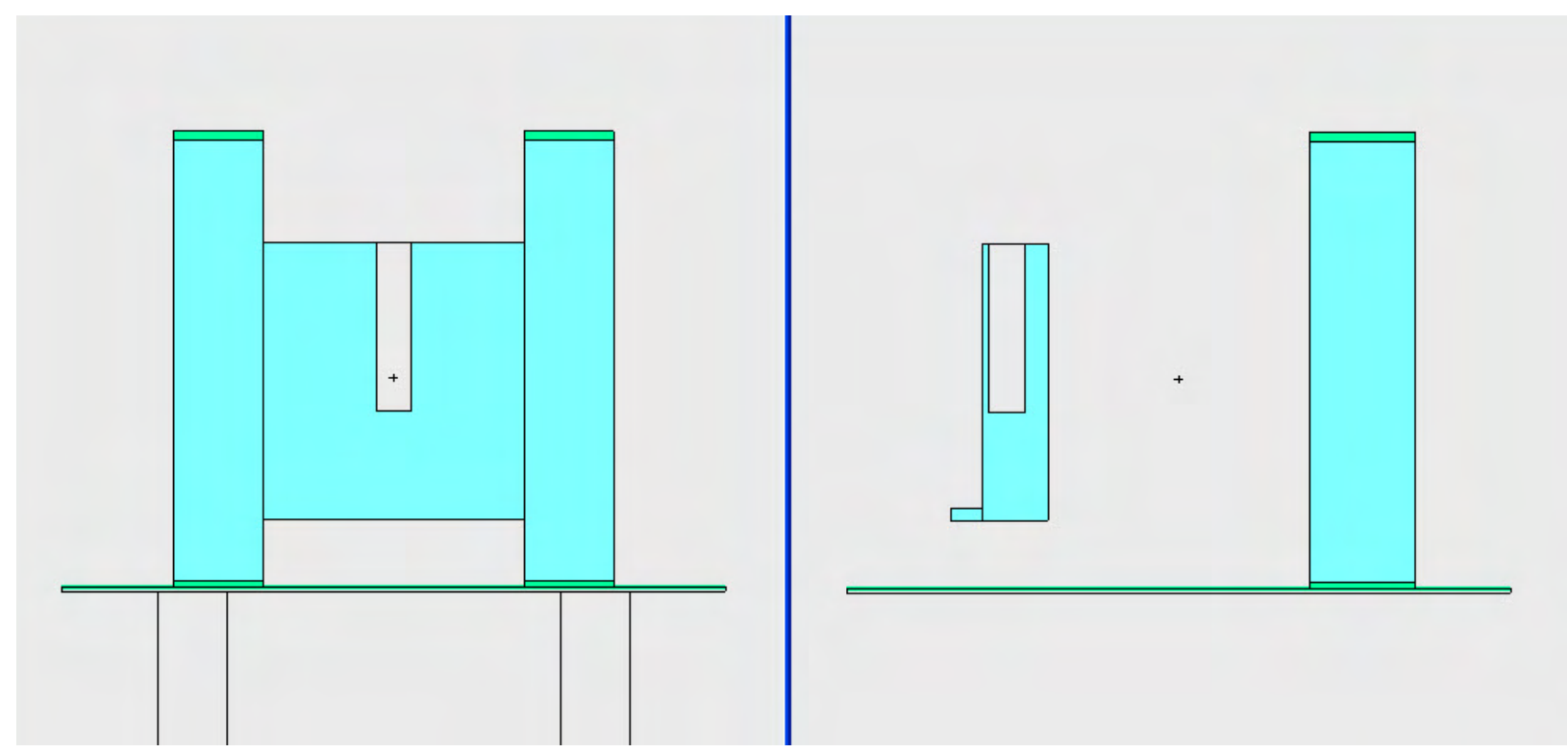

Figure 2.4. Views of the UNCL-II PWR model for the active source holder.

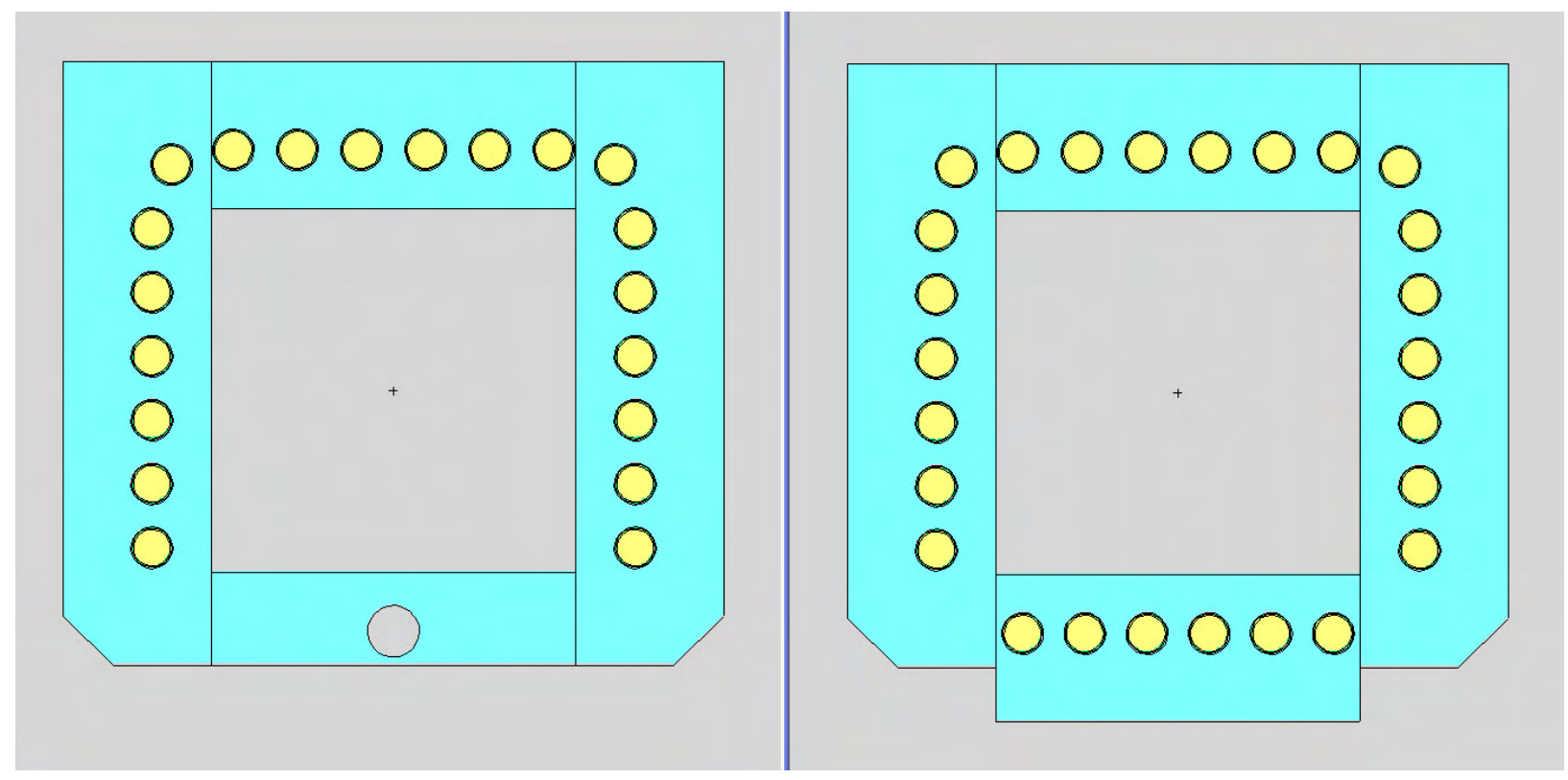

Figure 2.5. Views of the UNCL-II PWR model for active (left) and passive (right) configurations.

\subsection{BWR Models}

The BWR models were developed in a similar manner to the PWR models. The UNCL-II BWR model geometries were created based on a figure in the LANL model characterization study [Croft et al. 2011], correlated with dimensional information from previous LANL works [Croft et al. 2011; Menlove et al. 1990]. Figure 2.6 shows the comparison of the active UNCL-II BWR 
model and the UNCL-I BWR model. To change the UNCL-I configuration from PWR to BWR, the sides are closer together, while the UNCL-II BWR detector is a different design from the PWR version.

Figure 2.7 shows the comparison of the passive UNCL-II BWR model and the UNCL-I BWR model. In those passive configurations, the source holder of the active design is replaced with a fourth bank of detectors. As with the PWR models above, the fourth bank of detectors were assumed to be a mirror image of the bank on the opposite side of the fuel cavity.

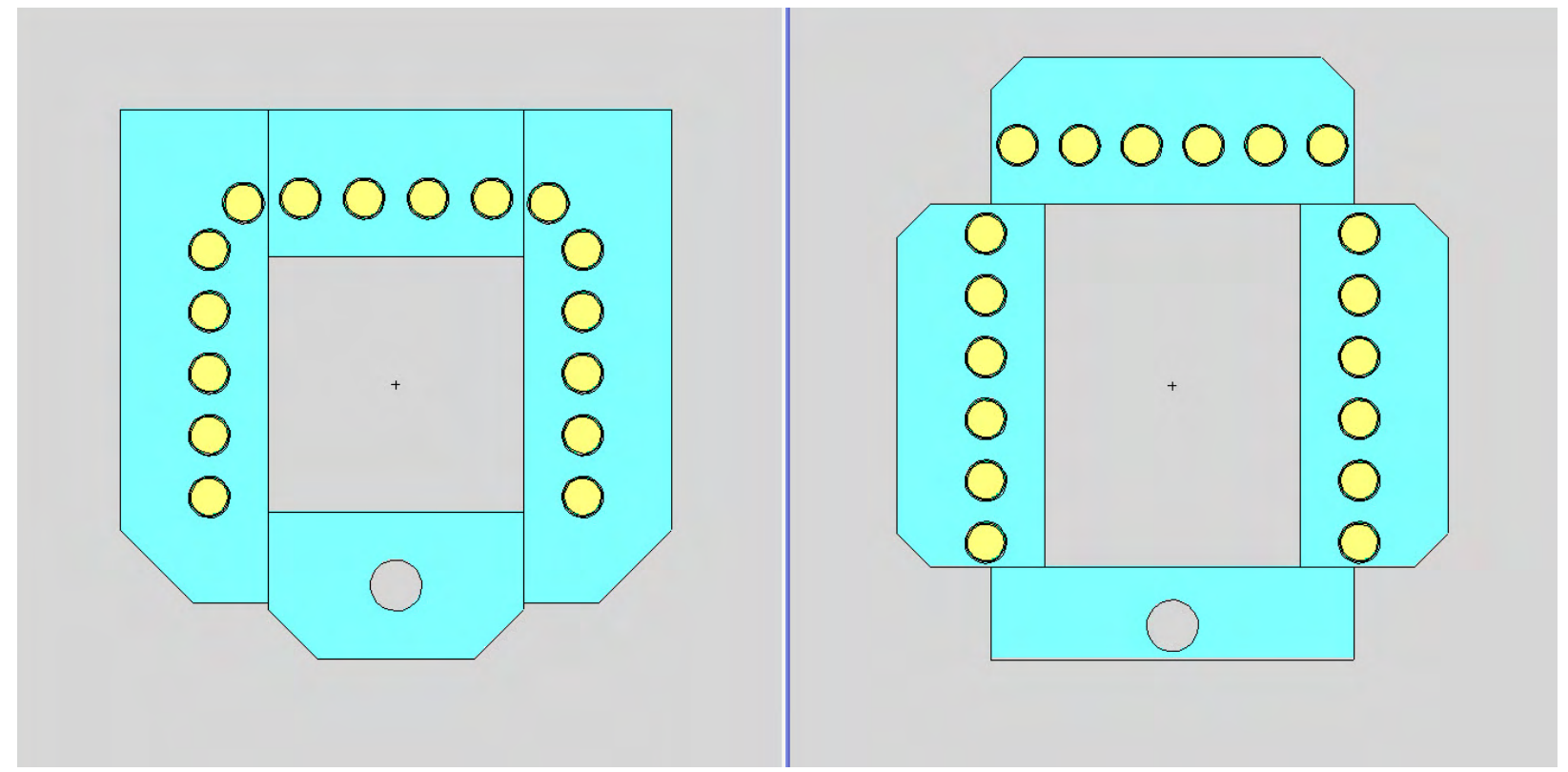

Figure 2.6. Comparison of the active UNCL-II BWR model (left) and the UNCL-I BWR model (right).
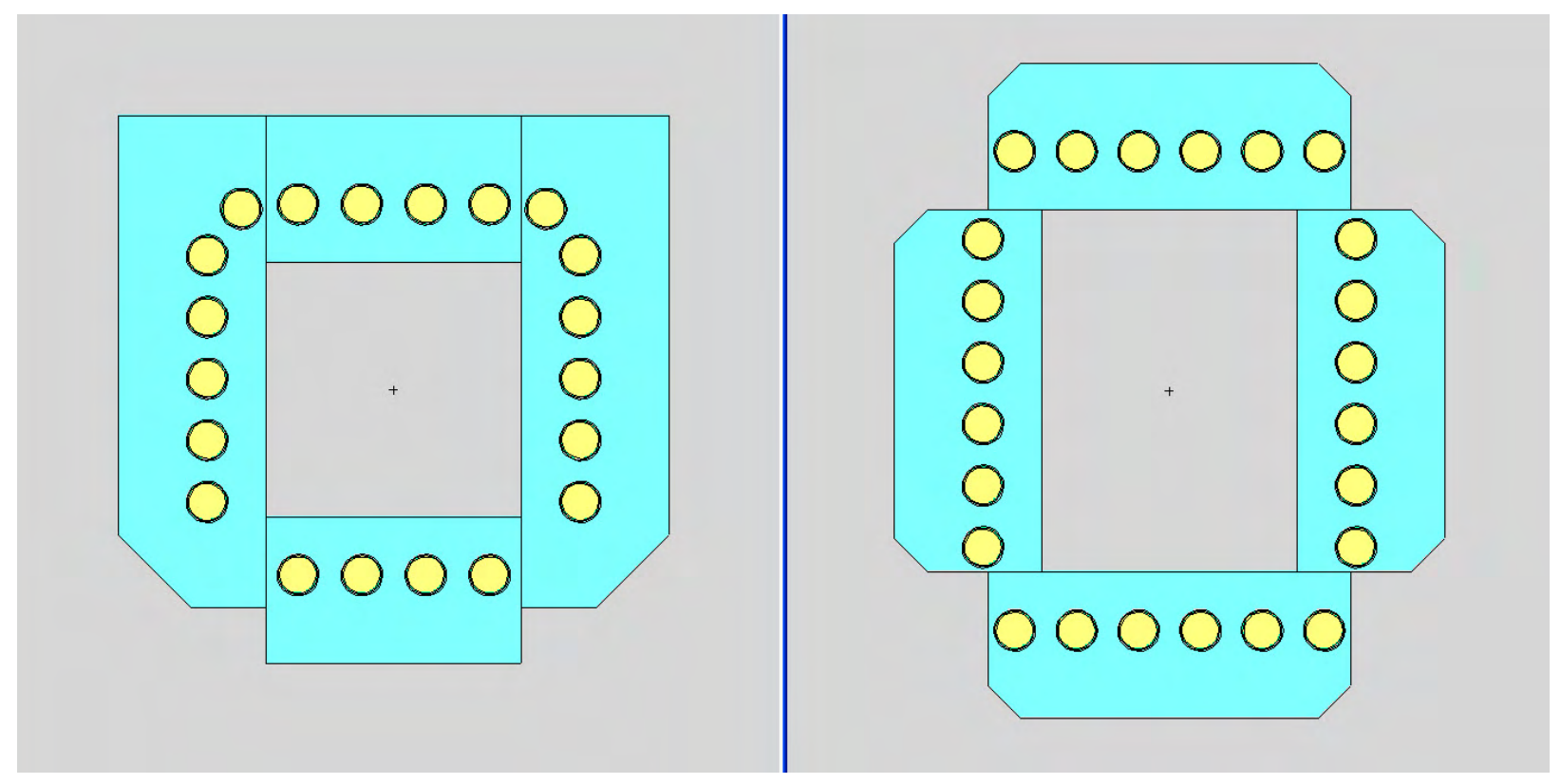

Figure 2.7. Comparison of the passive UNCL-II BWR model (left) and the UNCL-I BWR model (right). 
Figure 2.8 shows the comparison of the active UNCL-II PWR model and the BWR model. The BWR version is seen to be a separate design with a smaller chamber to fit the smaller BWR fuel assembly.

Figure 2.9 shows the comparison of the passive UNCL-II PWR and BWR configurations. As with the designs above, the passive configurations for these models replace the source holder of the active design by a fourth bank of detectors assumed to be a mirror image of the opposite bank of detectors.

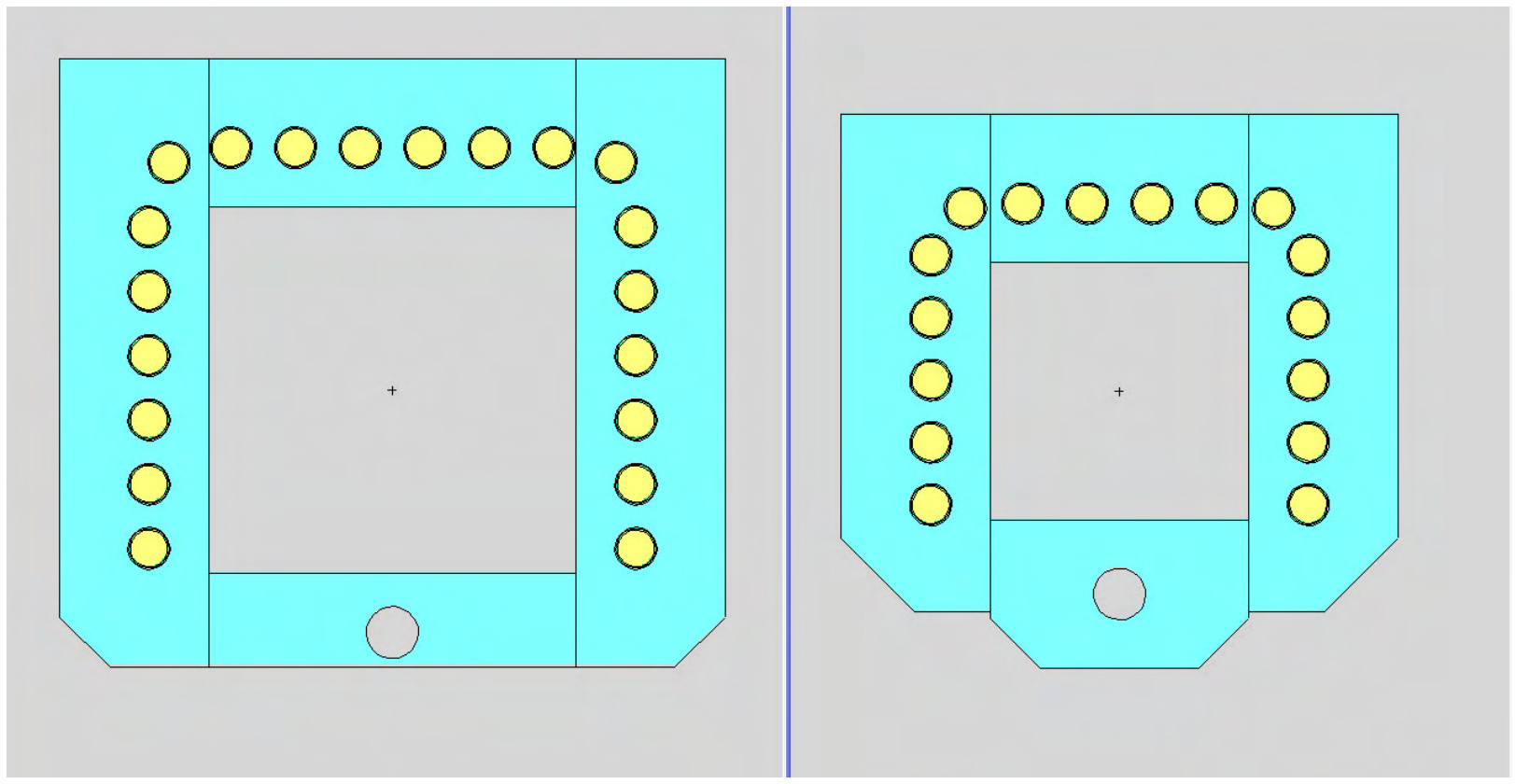

Figure 2.8. Comparison of the active UNCL-II PWR model (left) and the BWR model (right).

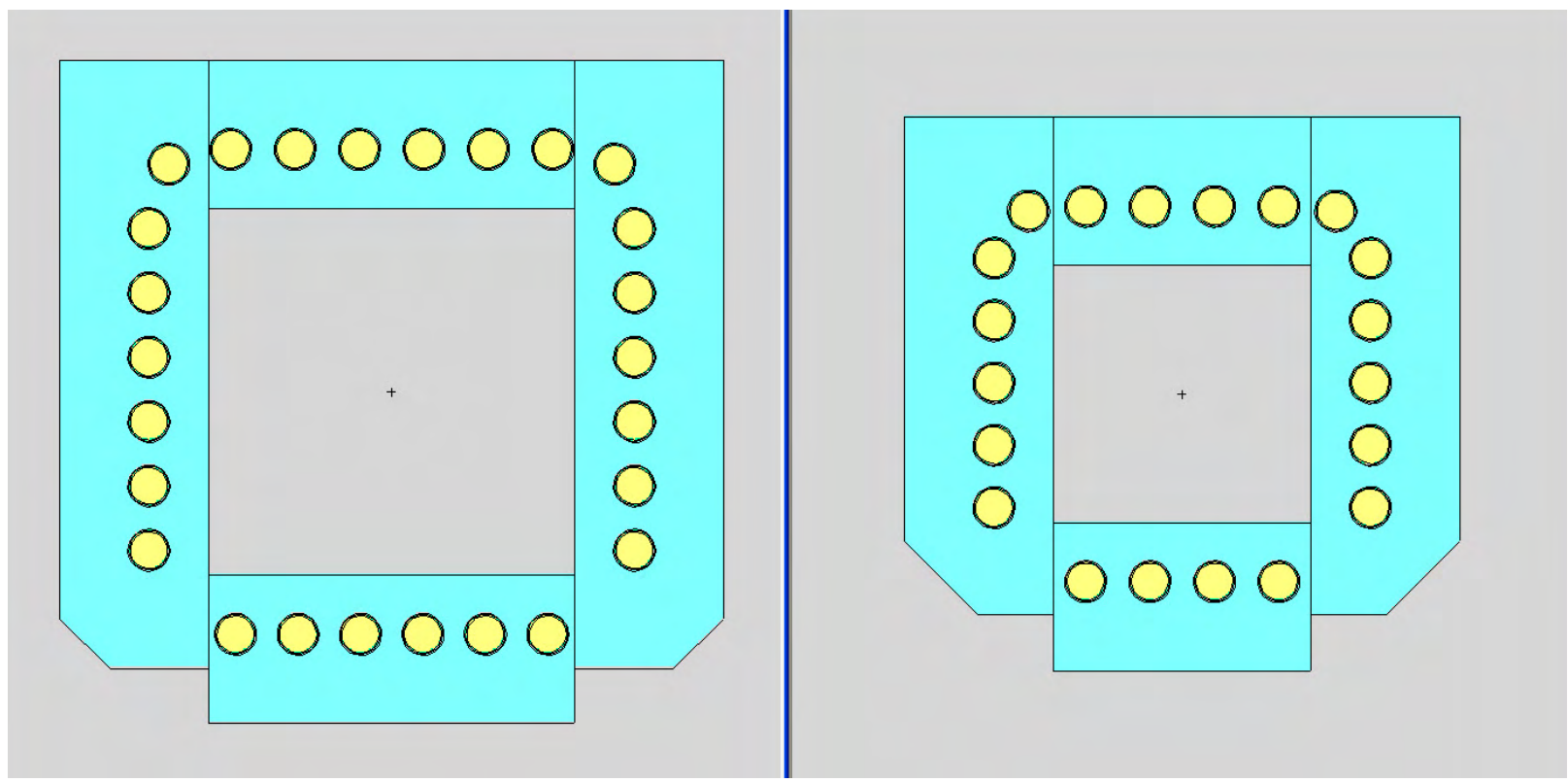

Figure 2.9. Comparison of the passive UNCL-II PWR model (left) and the BWR model (right). 


\section{UNCL Modeling Results}

This section summarizes the results of the various model configurations that were evaluated. Table 1.1 contains the results from these models for the total capture-reaction count efficiencies (F4 tallies) and single exponential fits (to F4 time bins) for the die away times. All evaluations had the detectors resting on a thin aluminum table that was $65.9 \mathrm{~cm}$ above a concrete floor.

\subsection{UNCL-I PWR Model Results}

The MCNPX model of the UNCL-I PWR configuration was created to compare the computed efficiency and die away time for detecting a ${ }^{252} \mathrm{Cf}$ source centered in the detector volume to the published values.

Figures 3.1 and 3.2 show examples of the exponential fits to the model results that predict the die away time for the counters. The die away time determined for the UNCL-I active PWR model was $49 \mu$ s. The corresponding die away time for the passive PWR model was $50 \mu \mathrm{s}$, compared to a reported value of $51 \mu$ s [Canberra 2011] for the passive JCC-71 (PWR UNCL-I).

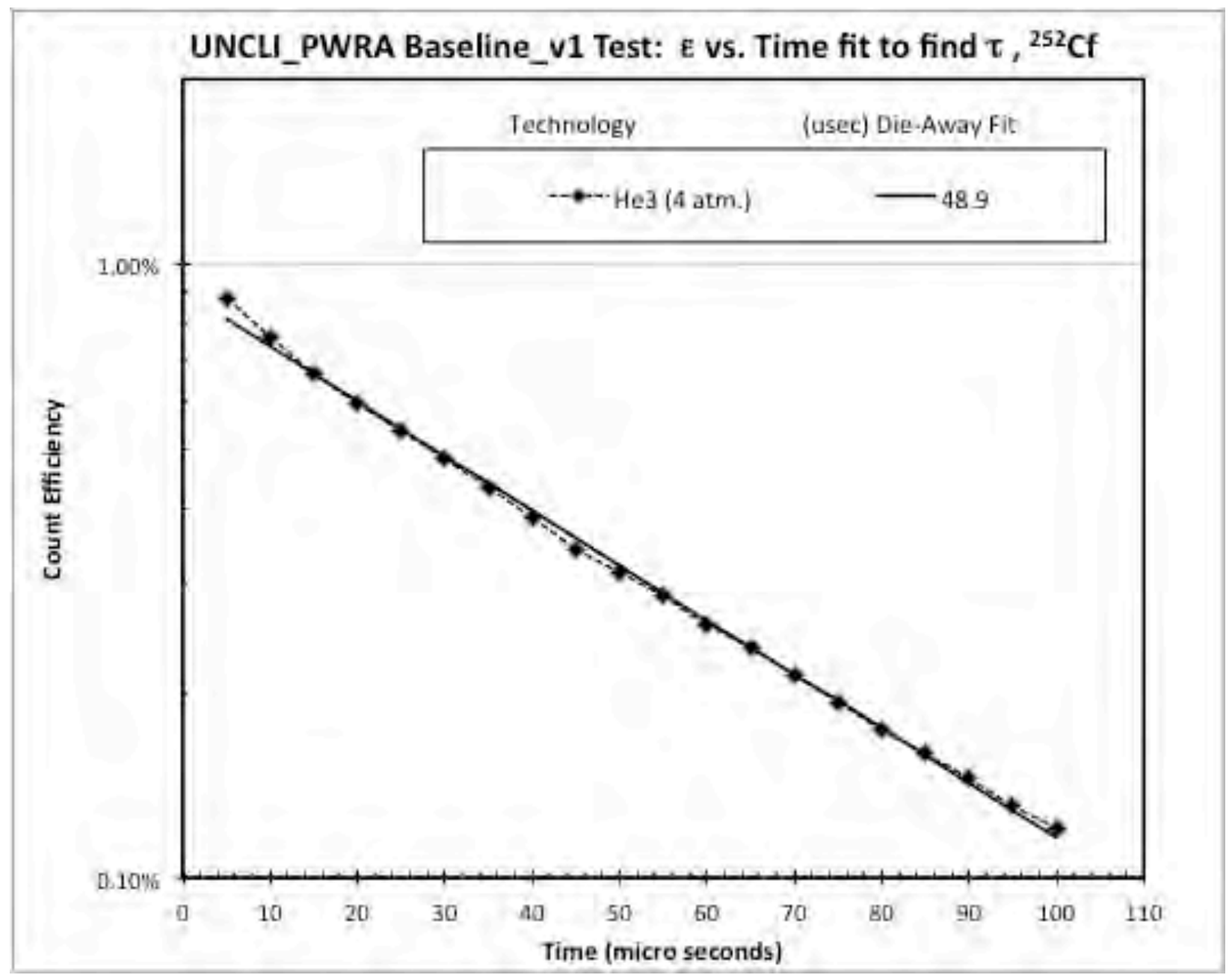

Figure 3.1. Results for active UNCL-I PWR die away time computed with the model.

Page 9 of 22 
The efficiency results from the MCNPX model for a PWR configuration of the UNCL-I was $12.2 \%$ (passive) and 9\% (active). This can be compared to the value stated by Canberra of $11.5 \%$ $( \pm 10 \%)$ for the passive PWR configuration [Canberra 2011], and by LANL of $10.3 \%$ for the active PWR configuration [Menlove et al. 1990].

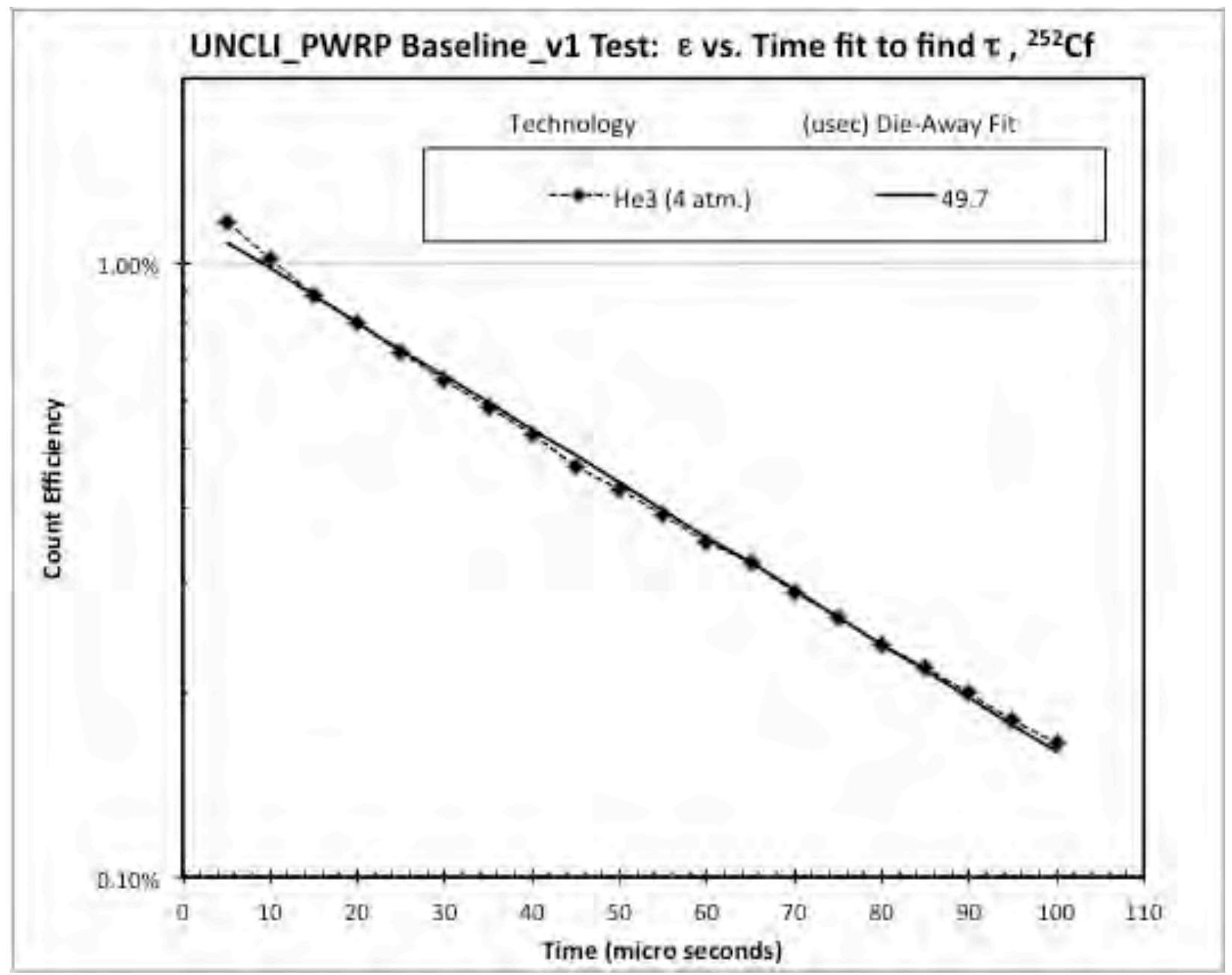

Figure 3.2. Results for passive UNCL-I PWR die away time computed with the model.

\subsection{UNCL-I BWR Model Results}

The UNCL-I BWR active configuration has been described by LANL, and has a reported efficiency of 13.5\% [Menlove et al. 1990]. This can be compared to the model result for the efficiency of $12.5 \%$, and a die-away time of $50 \mu \mathrm{s}$. For the passive configuration, for which there is no experimental value for comparison, the model result for the efficiency was $16.3 \%$, with a die-away time of $51 \mu \mathrm{s}$. The measured efficiencies were obtained with a ${ }^{252} \mathrm{Cf}$ source in the center of the cavity, not the center of the indicated fuel position [Menlove et al. 1990]. 


\subsection{UNCL-II PWR Model Results}

The MCNPX model of the UNCL-II configuration was created in order to compare the computed efficiency for detecting a ${ }^{252} \mathrm{Cf}$ source centered in the detector volume to the published efficiency values, where available.

The result from the MCNPX model was an efficiency of $12.3 \%$ for the active PWR configuration of the UNCL-II. This can be compared to the value stated by Canberra for the JCC-73 of $12.5 \%$ $( \pm 10 \%)$ [Canberra 2011] and that stated by LANL of 12.6\% [Menlove et al. 1990].

The die away time determined by the model was $53 \mu$ s. Figure 3.3 shows the exponential fit to the model results that give this die away time.

For the passive PWR configuration of the UNCL-II, for which there is no experimental value for comparison, the model result for the efficiency was $16.3 \%$, with a die-away time of $53 \mu \mathrm{s}$.

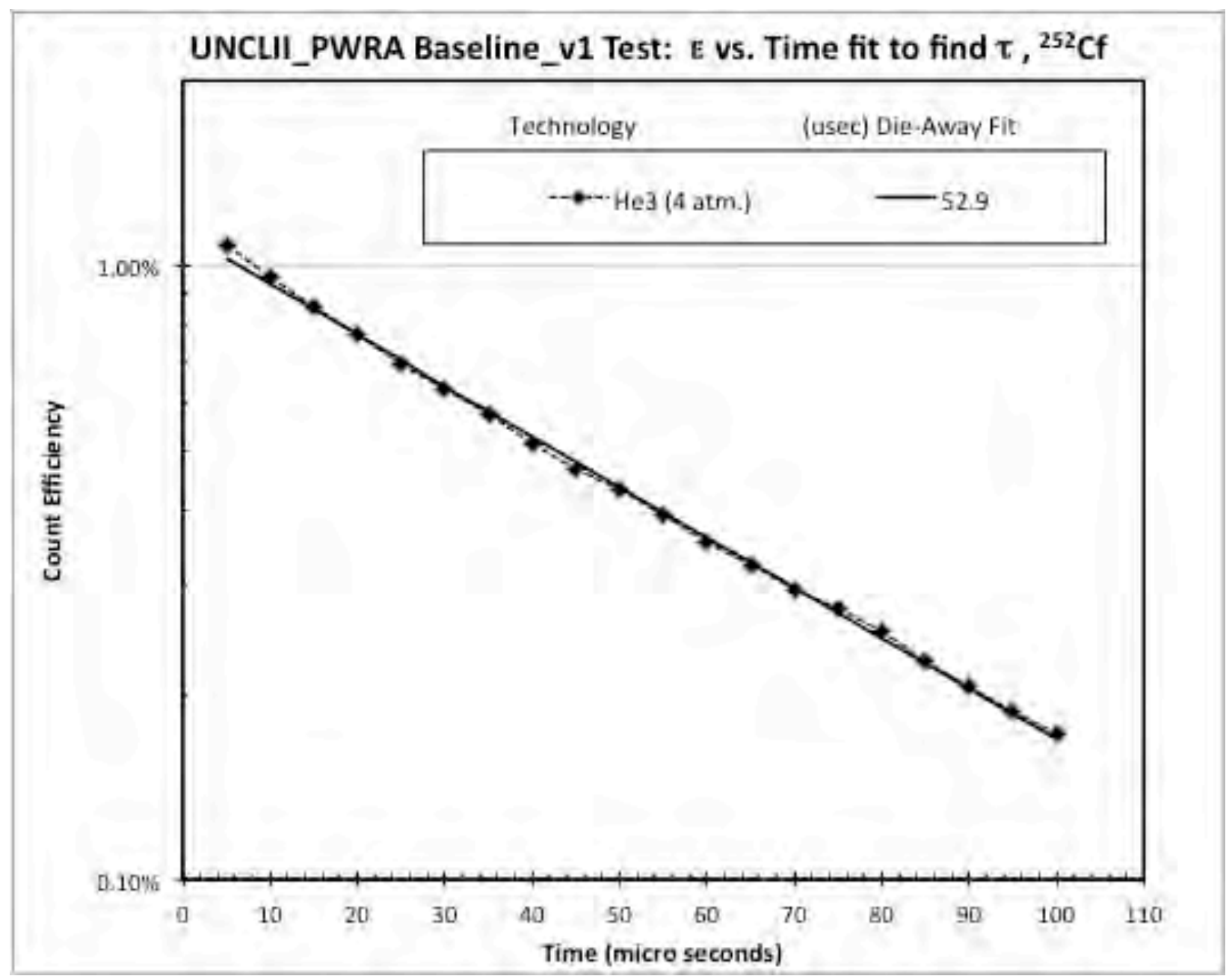

Figure 3.3. Results for active UNCL-II PWR die away time computed with the model. 


\subsection{UNCL-II BWR Model Results}

The UNCL-II BWR active configuration has been described by LANL; an efficiency of $15.3 \%$, with an effective, single exponential die-away time of $58( \pm 1.2) \mu$ s was reported [Croft et al. 2011]. This can be compared to the model result for the efficiency of $14.9 \%$, and a die-away time of $53 \mu \mathrm{s}$. The discrepancy in die away time could be due to the different methods used to calculate it. Croft et al. used the F8 CAP tallies for different gate $(\mathrm{G})$ values to calculate the two sets of coincidence rates ( $\mathrm{R}$ values) and use those results to evaluate Eq.1.2, where in this work the effective die-away times were obtained by fitting a single exponential to the capture tallies as a function of time. For the passive configuration, for which there is no experimental value for comparison, the model result for the efficiency was $19.1 \%$, with a die-away time of $54 \mu \mathrm{s}$. 


\section{Conclusions}

This report provides the results of the effort to model ${ }^{3} \mathrm{He}$-based UNCL neutron coincidence counters for applications in safeguards for Task 2 of the project Coincidence Counting With Boron-Based Alternative Neutron Detection Technology.

Models were created for eight possible UNCL configurations (UNCL-I or UNCL-II, active or passive, PWR or BWR), though all eight of these have not been physically constructed.

Results summarized in Table 1.1 show that the MCNP models can match the experimental measurements for efficiency and die-away time, where they exist, to within $10 \%$. Some of this difference can likely be accounted for by differences in the geometry of the physical detectors compared to the models, where dimensions were taken from design drawings or published representations rather than from as built drawings.

The next step in this project will be to model the UNCL configurations using boron-lined tubes in place of the ${ }^{3} \mathrm{He}$ tubes. The first step will be to do a one-for-one replacement of the ${ }^{3} \mathrm{He}$ tubes with equivalent sized boron-lined tubes. For completeness, this modeling will be performed for all eight configurations of the UNCL.

Only one configuration will be pursued for further detailed modeling to try to obtain comparable performance with the ${ }^{3} \mathrm{He}$-based UNCL through the addition of more tubes. That effort will be directed at the passive UNCL-II BWR configuration since LANL has a ${ }^{3} \mathrm{He}$-based system available for testing, and it is well documented [Croft et al. 2011]. 


\section{References}

Canberra. 2011. Model JCC-71, 72 and 73 Neutron Coincidence Collars. Accessed at www.canberra.com.

Croft S, A Favalli, MT Swinhoe, CD Rael. 2011. State Of The Art Monte Carlo Modeling Of Active Collar Measurements And Comparison With Experiment. Los Alamos National Laboratory. INMM Conference Record 2011.

ESARDA. 2005. Active Neutron Coincidence Counting Techniques for ${ }^{235} \mathrm{U}$ Mass Determination.

Henzlova D, LG Evans, HO Menlove, MT Swinhoe, JB Marlow. 2010. Test Program to Compare Alternative Neutron Detectors for Potential ${ }^{3}$ He Replacement for Nuclear Safeguards Applications. Los Alamos National Laboratory, Safeguards Science and Technology Group (N1) Report LA-UR-11-00098.

Henzlova D, LG Evans, HO Menlove, MT Swinhoe, V Henzl, C Rael, I Martinez, JB Marlow. 2012. Results of the Evaluation and Comparison of Alternative Neutron Detectors for Potential ${ }^{3}$ He Replacement for Nuclear Safeguards Applications. Los Alamos National Laboratory Report LA-UR-12-00837.

Kouzes RT, JH Ely, AT Lintereur, ER Siciliano. 2012. Introduction to Neutron Coincidence Counter Design Based on Boron-10. PNNL Report PNNL-21090, Pacific Northwest National Laboratory, Richland, WA.

PANDA. 1991. Passive Nondestructive Assay of Nuclear Materials (PANDA), Nuclear Regulatory Commission NRC-FIN-A7241. Los Alamos National Laboratory Report LA-UR-90732. Available at http://www.lanl.gov/orgs/n/n1/panda/index.shtml.

Pelowitz DB (ed.). 2011. MCNPX User's Manual, Version 2.7.0. Los Alamos National Laboratory Report LA-CP-11-00438.

Menlove HO. 1981. Description and Performance Characteristics for the Neutron Coincidence Collar for the Verification of Reactor Fuel Assemblies, Los Alamos National Laboratory Report LA-8939-MS.

Menlove HO, JE Pieper. 1987. Neutron Collar Calibration for Assay of LWR Fuel Assemblies, Los Alamos National Laboratory Report LA-10827-MS.

Menlove HO, JE Stewart, SZ Qiao, TR Wenz, PD Verrecchia. 1990. Neutron Collar Calibration and Evaluation for Assay of LWR Fuel Assemblies Containing Burnable Neutron Absorbers, Los Alamos National Laboratory Report LA-11965-MS.

Smith DB and GR Jaramillo. 1989. Los Alamos National Laboratory Report LA-11914-PR. 


\section{Acknowledgements}

The United States Department of Energy Office of Nuclear Safeguards (NA-241) supported this work. Pacific Northwest National Laboratory is operated for the United States Department of Energy under contract DE-AC05-76RLO 1830. Azaree Lintereur is a post-Masters Research Assistant supported at Pacific Northwest National Laboratory by the Next Generation Safeguards Initiative, Office of Nuclear Safeguards and Security, National Nuclear Security Administration. Jeremy Rogers is a Masters intern supported at Pacific Northwest National Laboratory by the Next Generation Safeguards Initiative, Office of Nuclear Safeguards and Security, National Nuclear Security Administration. 


\title{
7. Appendix A: Uranium Neutron Coincidence Collar
}

\author{
(This Appendix is extracted from [Kouzes et al. 2012])
}

Coincidence counters utilize an array of neutron detectors in a configuration that produces an optimal combination of high neutron detection efficiency and low neutron die-away time. The high efficiency allows coincident neutrons from fission events to be detected among a background of singles neutrons from various processes. Large detection efficiency is required because the efficiency for detecting coincidences varies as the square of the singles efficiency divided by the die-away time. A shift register is typically used to determine the coincidence count rate between the detectors due to fission in Pu or U. These coincident and singles count rates, along with assumptions about multiplication, provide a measurement of fissile mass.

For coincidence counting, the detection efficiency $(\varepsilon)$ and the die-away time $(\tau)$, which is a measure of how long the neutron takes to slow down (thermalize) and be captured, are the two important parameters. These two key parameters are typically combined to provide a figure-ofmerit (FOM), which is optimized for system performance, given by:

$$
\mathrm{FOM}=\varepsilon^{2} / \tau
$$

This FOM is a simplification of the equation [Smith and Jaramillo1989]:

$$
F o M=\frac{\varepsilon^{2}}{\tau s_{E} s_{Z}}
$$

where $\mathrm{s}_{\mathrm{E}}$ is efficiency as a function of energy and $\mathrm{s}_{\mathrm{Z}}$ is efficiency as a function of vertical position.

The UNCL is used for verification of ${ }^{235} \mathrm{U}$ in low enriched $\mathrm{U}$ fuel assemblies [Menlove 1981; Menlove et al. 1990]. An example of a UNCL is shown in Figure 7.1 taken from ESARDA [2005].

Measurement of the fissile mass of uranium samples generally requires active techniques due to the low spontaneous fission yields of all the uranium isotopes. Using an external source of neutrons (such as americium-lithium [AmLi]) will induce fission in ${ }^{235} \mathrm{U}$, resulting in multiple neutrons per fission (mean of 2.41 neutrons per fission induced by thermal neutrons in ${ }^{235} \mathrm{U}$ ) that can be measured in coincidence. Coincidence counting with a shift register allows for discrimination between the external source neutrons and neutrons from uranium fission.

Coincidence Collars use three or four banks of detectors surrounding a sample, and are used for measuring fresh fuel assemblies. Measurement of Pu in mixed oxide (MOX) fuel with a Coincidence Collar can be done in passive mode (without external source). For uranium fuel measurements, active mode is used with three bank detectors, each containing four ${ }^{3} \mathrm{He}$ tubes, and a source on the fourth side. The mass of the uranium is determined from this process with an accuracy of $1-5 \%$ in measurement times of a few hundred seconds. Figure 7.1 shows an UNCL in active mode with fuel rods loaded between two of the three bank detectors (the fuel obstructs the third bank), and the interrogation source location in the foreground. 


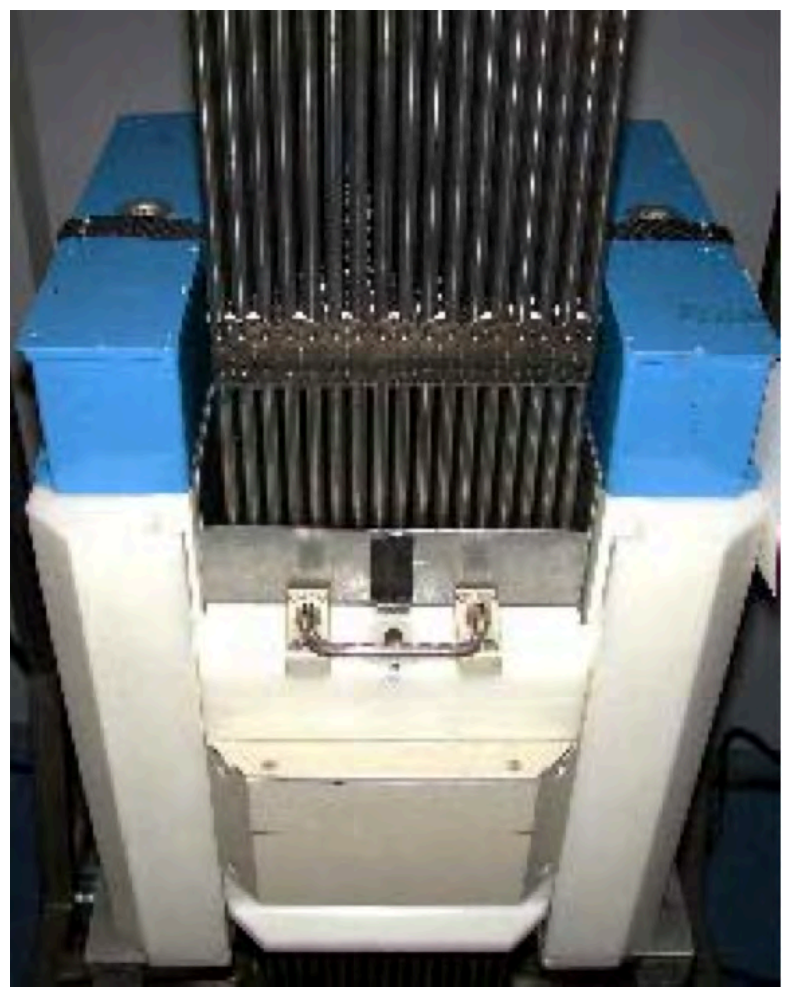

Figure 7.1. Uranium Neutron Coincidence Collar (UNCL) [ESARDA 2005].

\subsection{Canberra Uranium Neutron Coincidence Collar}

Canberra (Meriden, CT) manufactures three models of the UNCL based on the UNCL-I [Menlove 1981], as described on their web site [Canberra 2011]:

"The Model JCC-71 Neutron Coincidence Collar is a passive/active neutron counter for the measurement of the ${ }^{235} \mathrm{U}$ content per unit length in fresh PWR, BWR and CANDU fuel assemblies. The JCC-71 can also be used to measure the plutonium content of MOX fuel. The system design is based on technology transfer from the Los Alamos National Laboratory.

The JCC-71 is made up of four counter banks, each composed of high-density polyethylene for the moderation of the fission neutrons. Each bank contains several ${ }^{3} \mathrm{He}$ detectors for the detection of neutrons. The counter can operate in both an active mode and a passive mode. For the passive mode, all four counter banks are used around the fuel assembly. If operated in the active mode, one bank of detectors is replaced with a polyethylene bank containing only an Americium-Lithium (AmLi) interrogating source. (The AmLi source must be ordered separately.)

In the active mode, the AmLi source is required to interrogate the fuel, and coincidence counting of the induced fission neutrons from $235 \mathrm{U}$ is performed. The AmLi source is contained in a tungsten source bottle and placed inside the polyethylene bank. The AmLi neutrons are thermalized in the polyethylene and induce fission in the ${ }^{235} \mathrm{U}$. The average energy from the induced fission is higher than the moderated AmLi neutrons and gives fast neutron multiplication, which allows the measurement to penetrate into the interior of the 
fuel assemblies. For HEU fuel, cadmium liners can be added to improve neutron penetrability.

To measure the ${ }^{238} \mathrm{U}$ content, the bank with the AmLi source is replaced by the fourth bank of ${ }^{3} \mathrm{He}$ detectors, and the counter is operated in a passive mode, counting the coincidence neutrons from spontaneous fission of ${ }^{238} \mathrm{U}$. The collar measures the ${ }^{235} \mathrm{U}$ and ${ }^{238} \mathrm{U}$ content along the axis of the assembly, not the enrichment. Since the ${ }^{235} U$ content is of primary interest for safeguard purposes, only the active measurement is typically necessary. Pucontaining fuel rods are measured in the passive mode because of the relatively high spontaneous fission rate.

The JCC-71 Neutron Coincidence Collar is designed to allow modification of the geometry to closely couple the detectors with the fuel type. For the smaller BWR fuel, the side detector banks are moved into the inner screw-hole position. The fourth bank of ${ }^{3} \mathrm{He}$ detectors (used in passive mode) is hinged in order to facilitate placing the counter around fuel assemblies.

The Neutron Coincidence Collar is designed to be insensitive to parameters such as open channels for control rods, enrichments, angular orientation of the fuel in the Collar, fuel pellet density, and any protective bagging. Cladding type (zinc alloy or stainless steel), different fuel pellet diameters, and neutron absorbers $\left(\mathrm{Gd}_{2} \mathrm{O}_{3}\right)$ can affect the measurement.

A Neutron Coincidence Analyzer (or shift register), a computer, and analysis software are required for coincidence counting and must be purchased separately from the JCC-71.

The increased use of neutron collars at various facilities for measuring designated fuel types (BWR or PWR), led to two additional designs by Los Alamos National Laboratory. The two additional neutron collar counters are the JCC-72 for BWR and CANDU fuel assemblies, and the JCC-73 for PWR fuel assemblies."

Figure 7.2 through 7.6 show the design of the Canberra UNCL detectors taken from [Canberra 2011].

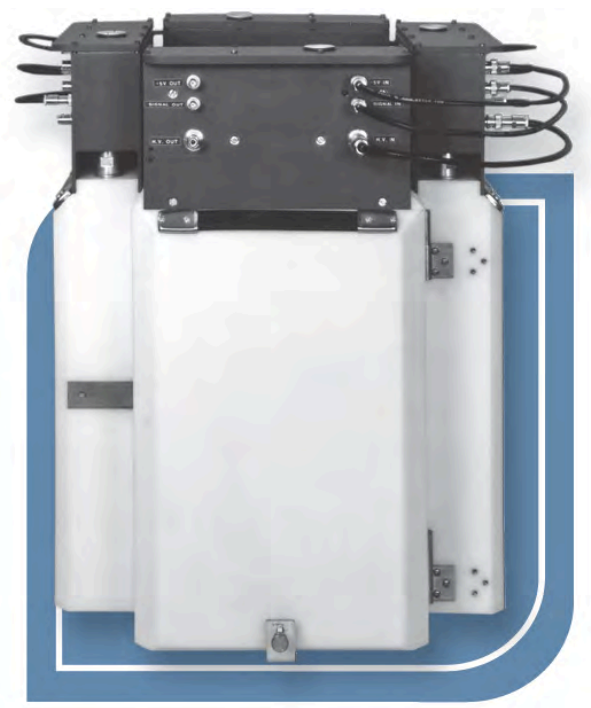

Figure 7.2. Canberra JCC-71 UNCL in Passive Configuration [Canberra 2011]. 


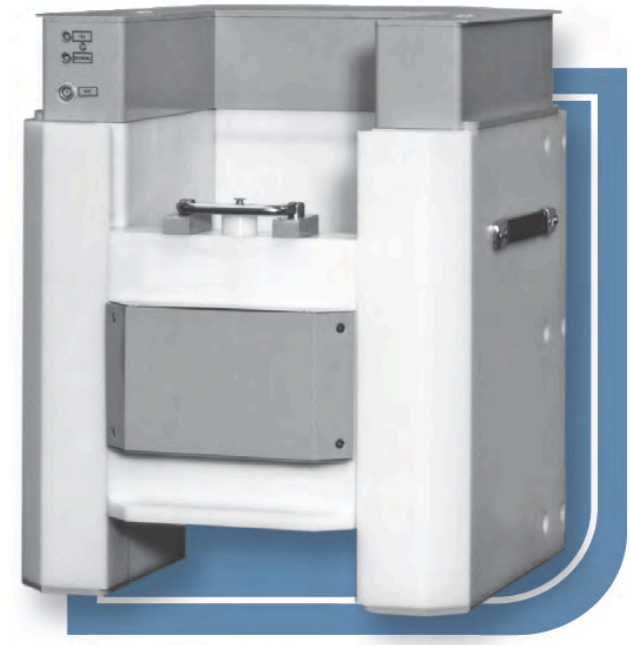

Figure 7.3. Canberra JCC-73 UNCL in Active Configuration for PWR fuel [Canberra 2011].

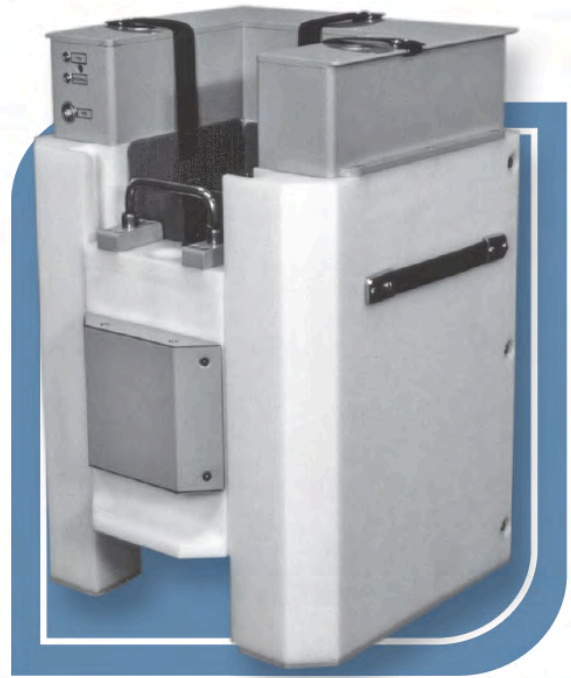

Figure 7.4. Canberra JCC-72 UNCL Active Configuration for BWR or CANDU fuel [Canberra 2011]. 

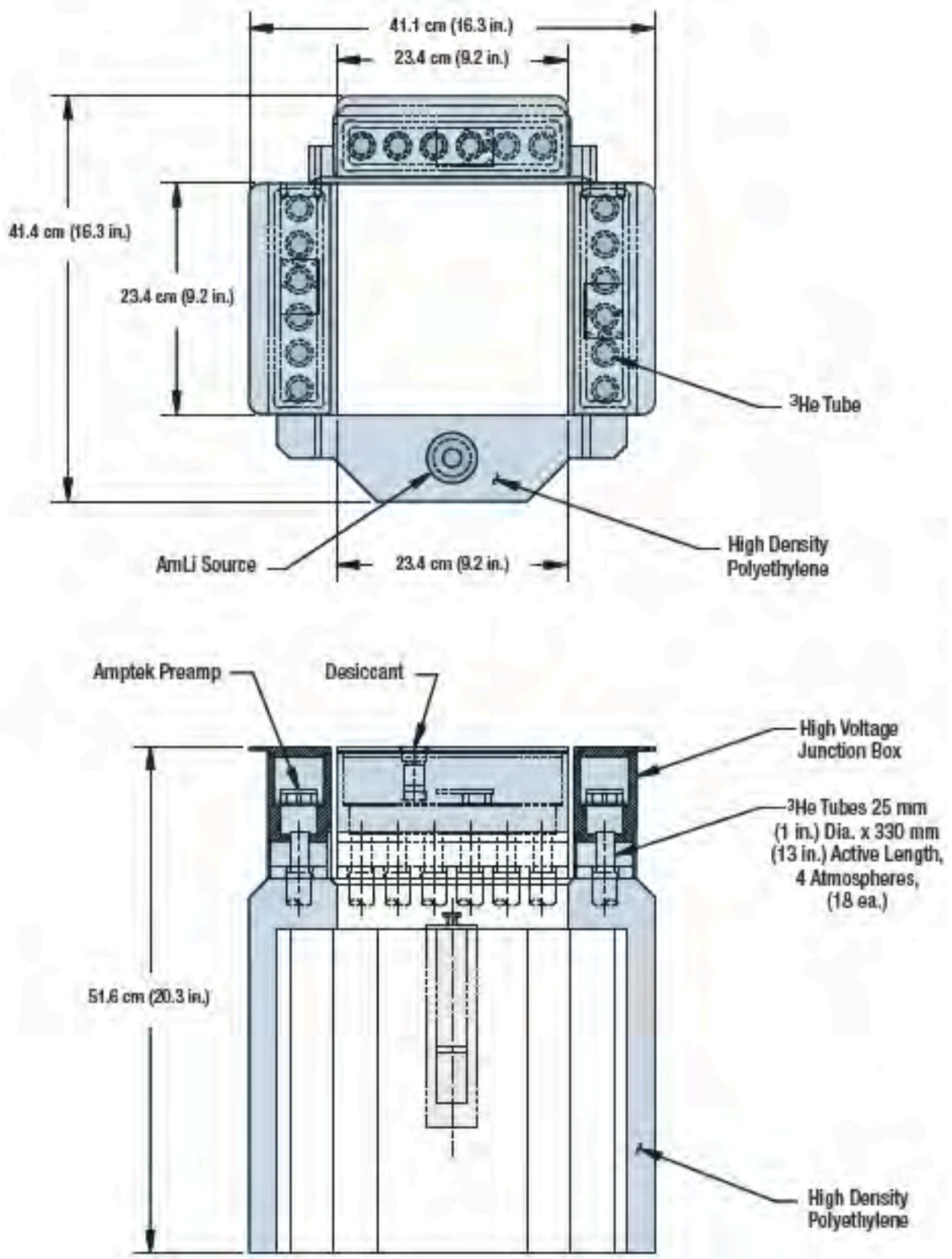

Figure 7.5. Canberra JCC-71 UNCL Schematic Active Configuration for PWR fuel [Canberra 2011]. 


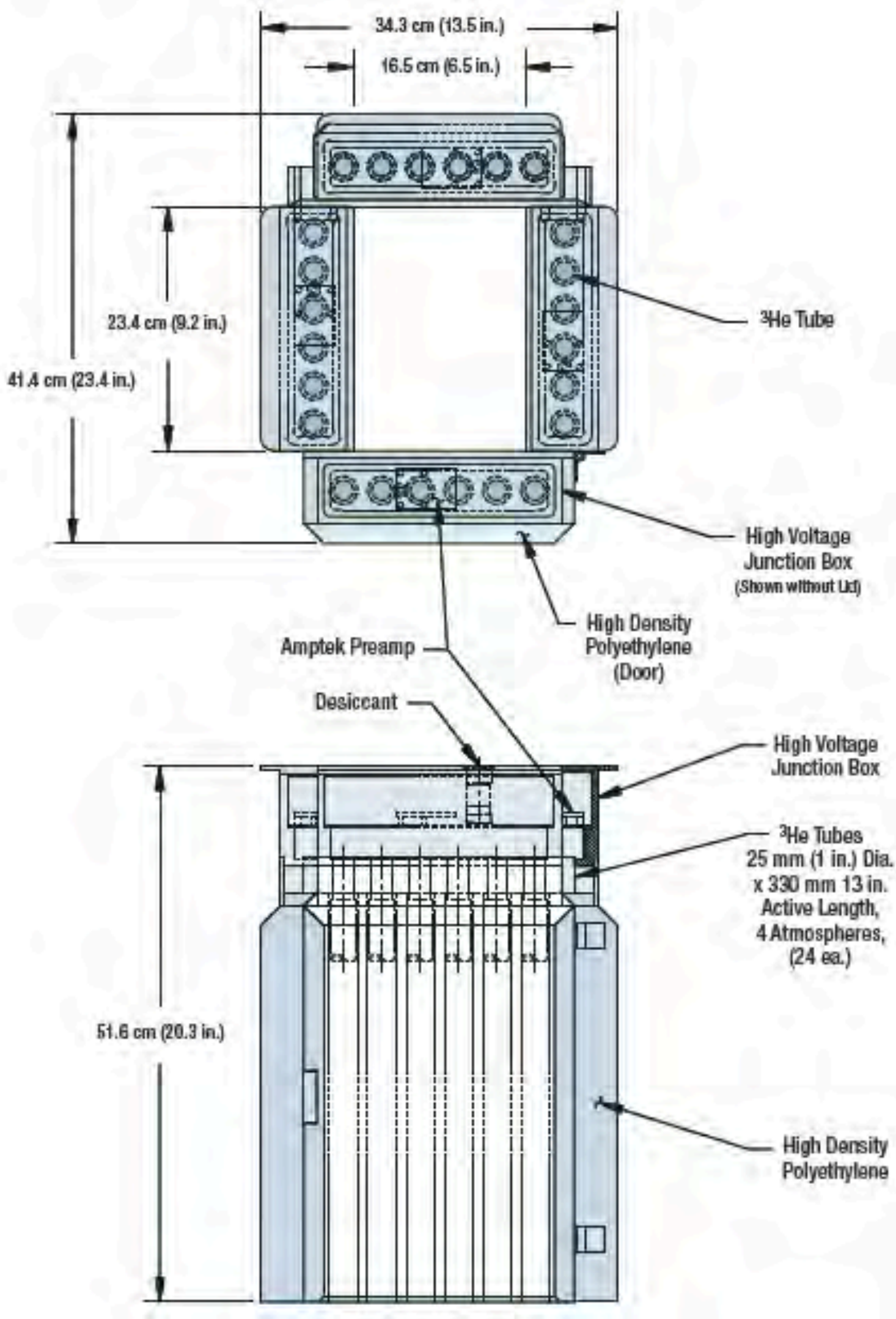

Figure 7.6. Canberra JCC-71 UNCL Schematic Passive Configuration for PWR fuel [Canberra 2011].

Page 21 of 22 


\subsection{LANL Uranium Neutron Coincidence Collar}

Los Alamos National Laboratory (LANL) has constructed both BWR and PWR uranium neutron coincidence collars that are designated as UNCL-I [Menlove 1981] and UNCL-II [Menlove et al. 1990]. The gas pressure in both UNCL designs is $4 \mathrm{~atm}$. The efficiency of the PWR UNCL for a ${ }^{252} \mathrm{Cf}$ source improved from $10.3 \%$ to $12.6 \%$ (no Cd mode) from the model I to the model II.

LANL has a $15 \times 15$ rod PWR fuel assembly in a shielded cell that can be used as the target for measurements to compare the existing ${ }^{3} \mathrm{He}$-based UNCL-II with a new ${ }^{10} \mathrm{~B}$-based UNCL system. The PWR system is the more important case for the study. The uniformity of response parameter is documented for the PWR UNCL-II case. In general, the PWR collar has better doubles precision than the BWR collar because of the higher fuel mass and multiplication. ${ }^{1}$

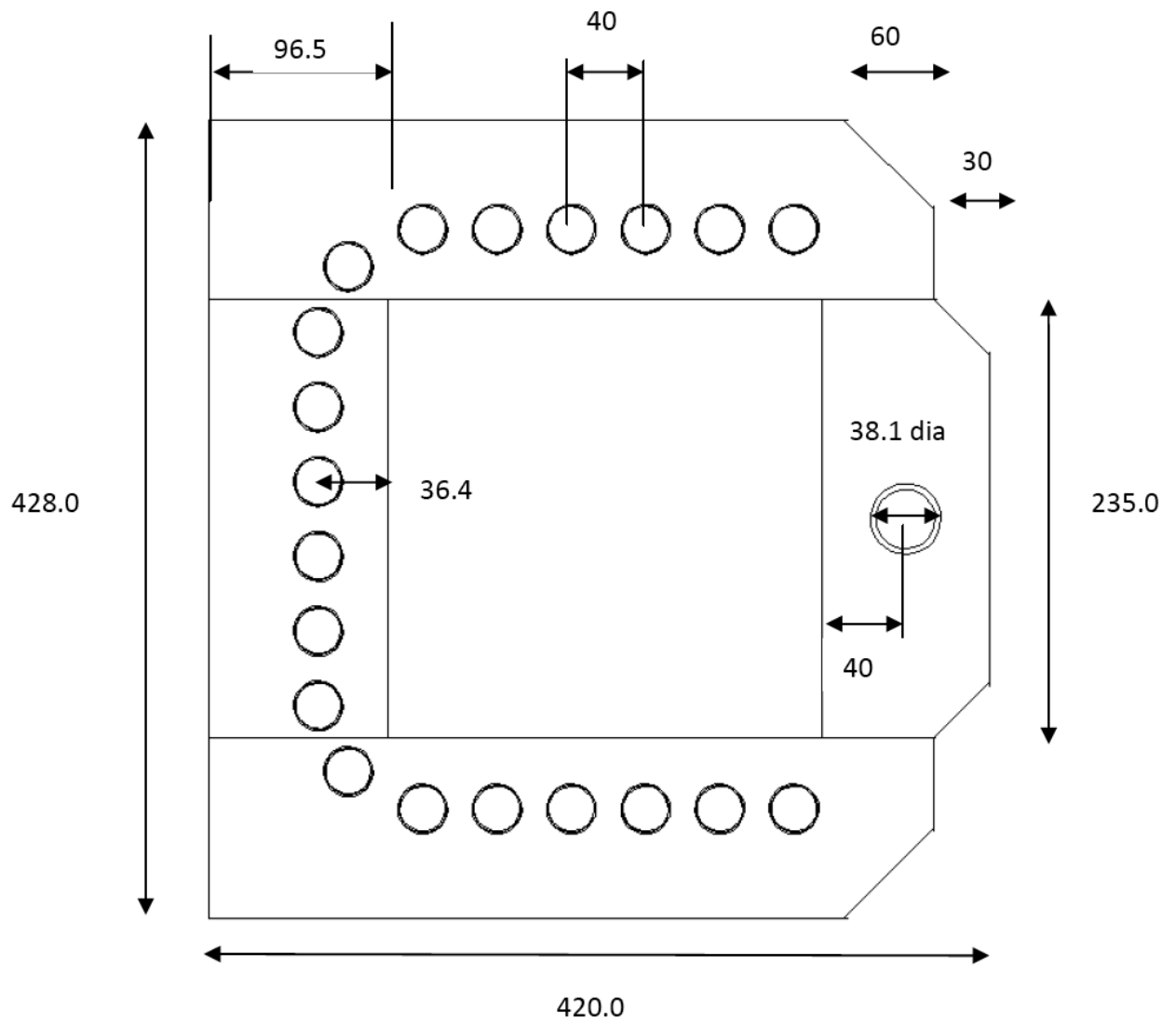

Figure 7.7. LANL UNCL-II Schematic (dimensions in mm).

Figure 7.7 shows a schematic of the LANL UNCL-II design [Menlove et al. 1990]. The UNCLII differs from the Canberra UNCL in that the UNCL-II there are two additional ${ }^{3} \mathrm{He}$ tubes (located at the inner corners), the back polyethylene is $6.5 \mathrm{~mm}$ thicker, and the polyethylene on the sides is $8.5 \mathrm{~mm}$ thicker. Both the UNCL and UNCL-II use $330 \mathrm{~mm}$ long active length ${ }^{3} \mathrm{He}$ proportional counters. The height of the poly in the UNCL-II is $412.8 \mathrm{~mm}$, and is somewhat shorter $(\sim 385 \mathrm{~mm})$ in the Canberra UNCL. Thus, the UNCL-II should have more efficiency than the Canberra UNCL due to the added ${ }^{3} \mathrm{He}$ tubes (20 versus 18 ).

\footnotetext{
${ }^{1}$ Howard Menlove, private communication, April 2012.
} 


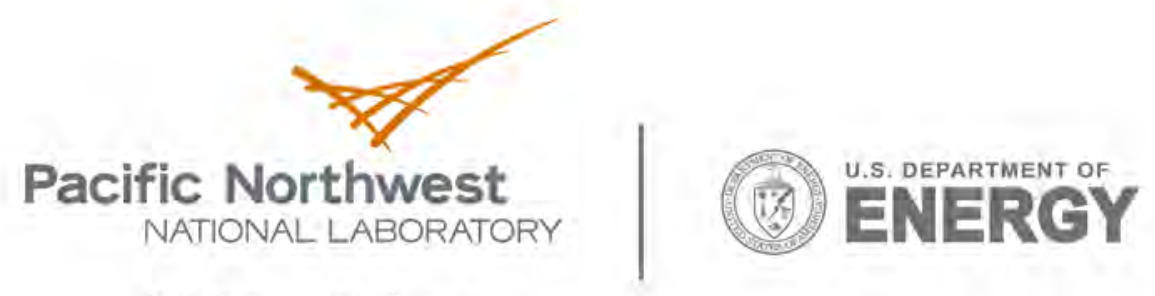

902 Battelle Boulevard

P.O. Box 999

Richland, WA 99352

1-888-375-PNNL (7665)

www.pnl.gov 